\title{
The problem of forming professional competence with the help of the russian language practical courses based on a course "In the world of PR"
}

\section{El problema de la formación de la competencia profesional con la ayuda de cursos prácticos del idioma ruso basados en un curso "En el mundo de las RP"}

\author{
Alexandr Petrov \\ Tauride Academy (SP), FGAOU VPO «Crimean Federal University named after \\ Vernadsky», Simferopol, Russia \\ ORCID ID: https://orcid.org/0000-0001-9377-9399 \\ Olga Fisenko \\ Peoples' Friendship University of Russia (RUDN University), Moscow, Russian \\ Federation \\ ORCID ID: https://orcid.org/0000-0002-3824-5535 \\ Amini Abdul Rahman \\ Peoples' Friendship University of Russia (RUDN University), Moscow, Russian \\ Federation \\ ORCID ID: https://orcid.org/0000-0001-9180-7384 \\ Petrova Luiza \\ SBEE HEI «Crimean Engineering and Pedagogical University named after Fevzi \\ Yakubova», Simferopol, Russia \\ ORCID ID: https://orcid.org/0000-0002-2936-4049
}

Received 07-07-20 Revised 09-25-20 Accepted 01-13-21 On line 01-25-21

*Correspondencia

Email: AlexandrPetrov@gmmail.com
Citar como:

Petrov, A., Fisenko. O., Rahman, A. A., \& Luiza, P. (2021) The problem of forming professional competence with the help of the russian language practical courses based on a course "In the world of PR". Propósitos y Representaciones8(2), e945. Doi: http://dx.doi.org/10.20511/pyr2020.v8n2.945 


\section{Resumen}

Resumen: Este artículo demuestra que la formación de competencias profesionales mediante el idioma ruso es un desafío difícil para los profesores de ruso como lengua extranjera. La competencia profesional es una construcción compleja que incluye la competencia comunicativa. Esto se debe a que las actividades de los profesionales en relaciones públicas implican la posesión de toda una gama de estrategias de comunicación empresarial, así como la capacidad de implementar diversos tipos de comunicación e impacto.

Palabras clave: relaciones públicas, lengua de especialidad, competencia profesional.

\section{Summary}

The article proves that formation of professional competence with the help of the Russian language is a daunting challenge which the professors of Russian as a foreign language often face. Professional competence is a complex construct including communicative competence. The matter is that the PR specialists' professional activity presupposes a wide range of business communications strategies, as well as different types of communication and leverage.

Keywords: PR, vocation-related language, professional competence

\section{Introducción}

The problem of forming professional competence at university is the main focus of professors who teach Russian as a foreign language and supervisors. With increased requirements for the specialists from different spheres the problem becomes especially urgent.

One of the most popular specialties among the foreign students, who come to study Russian, is Public Relations (PR). Its popularity is linked to broadened international contacts and the demand in specialists with an expertise in foreign languages and international communication. The bachelor graduates can work in PR agencies, press services, and public authorities.

Nowadays PR is juxtaposed to the general business strategy. The graduates get expertise in politics, economics, psychology, philosophy, marketing and other spheres, as well as PR technologies. The "Public Relations" speciality is characterized by the combination of economic and creative sides.

During their vocational training the foreign students, who have chosen "Public Relations" speciality as their future profession, learn to write texts, make video and photo coverage, develop projects in drawing programs, etc. That is why training of foreign students requires learning of vocation-related language. The proficient Russian language makes future specialists more motivated.

The relevance of the research is related to the fact that there is no experience in the formation of professional competence in foreign students who learn Russian.

\section{Background}

The modern strategy of higher education is based on active contextual education principle. That means that the current tendency of a modern educational process at universities is a convergence of educational and productive activity. If we take vocational training of PR students as an example, there active educational strategies are implemented due to the focus on communication. Therefore, the contents, the forms and the methods of education require an upgrade. With better quality of language training there is a need for creation of the pedagogical technologies which would provide the formation of professional competence.

The issue of the formation of professional competence has been studied for a long time. 
However, there is not enough data of professional competence among PR specialists. Researchers lack the information concerning the issues, related to the formation of professional competence among foreign students with the help of vocation-related language. The methodological base of our research includes the works by A.V. Koreneva (2009), P.I. Obraztsov and O. Yu. Ivanova (2005), as well as the researches on foreign-language verbal communication and the issues of teaching foreign students by S.A. Vishnyakov and L.A. Dunaeva (2017).

\section{Discussion Problems}

\section{The main principles of vocation-oriented education at Russian universities}

Vocation-oriented education is the priority of a modern educational process. During their study the PR foreign students improve their skills in speaking Russian and acquire the professional knowledge.

The vocation-oriented approach to teaching the future PR specialists is focused on the formation of communication skills in Russian in the field of their profession, business and science spheres and the situations related to them, regarding the specifics of professional thinking when organizing motivation-improving and research-focused activities. A vocation-related language course plays a vital role in vocation-oriented education (Kargina, Fisenko \& Polyanskaya 2017, p. 1970).

To summarize, vocation-oriented education create conditions for mainstreaming concerns in learning the language. In the context of vocation-related language the knowledge from different areas gets integrated so that the PR foreign students could obtain additional professional knowledge and professionally important competences.

\section{lessons}

Theoretical base of forming professional competence at Russian as a foreign language

The key notion of vocation-oriented education is professional competence, i.e. skills and personal qualities, which determine the way of exercising professional functions.

Professional competence consists of special and personal competences which include cognitive abilities, powers of observation, creativity, self-independence, and the ability to act in extreme circumstances. One of the basic professional competences of PR specialists is professional communicative competence which means the foreign students' linguistic potential they can freely exercise in interpersonal, intercultural, and professional with regard to the standards of modern Russian literary language, the ability to behave according to the professional sphere of communication and to successfully apply all professional communicative competences and skills obtained when overcoming a complex of professional challenges of any level of complexity.

The professional competences of PR specialists are based on professional standards adequate to the graduates' professional activity, as well as the analysis of professional competence requirements which the graduates are to meet, and generalized domestic and foreign practice.

The general professional competences include:

- the ability to create media and communication products and media texts, demanded by the society and industry, according to Russian and foreign-language standards and specifics of semiotic system;

- the ability to consider the tendencies in the development of public institutions to cover them in media and communication products and media texts in a comprehensive way;

- the ability to enjoy the diverse achievements of domestic and worldwide culture when creating media and communication products and media texts;

- the ability to respond to the demands and requests of the society and the professional sphere; 
- the ability to consider the tendencies in the professional sphere, concerning the development of media and communication systems in the region, country or in the world on the basis of their political and economic functioning, as well as legal and ethical standards;

- the ability to apply modern information communication technologies;

- the ability to consider the impact and the consequences of the professional activity, maintaining the standards of corporate responsibility.

\section{Experience in the formation of foreign-language communicative competence at the scientific language lessons, based on the Russian language as an example}

The practical course "In the world of PR" is a vocation-related language practical course for junior and senior year students. The textbook is intended for the PR speciality foreign students, who study Russian at the second certificate level. Based on specific language, the textbook help foreign students to develop professional skills in the field of vocation-related language and broaden their vocabulary. The course includes new professional vocabulary, lexical and grammatical constructions, which are necessary for reading specific texts, and lexical and grammatical exercises focused on the improvement of linguistic, communicative and professional competences.

Its first lesson called "Public Relations as a profession" familiarizes the foreign students to their future profession. They learn new terms and their meanings, along with their use and compatibility. There comes the analysis of the definitions of "Public Relations":

- PR is the art of forming the public's positive attitude to a firm, when there is an understanding that the firm makes and distributes its goods with regard to buyer's interests, not sellers' ones;

- PR is a deliberate organization of communication;

- PR is one of the management functions;

- PR is the science and art of maintaining mutual understanding and benevolence among a person, a firm, an institution and the public;

- PR is a management function, intended to evaluate the public's attitude, to determine the policy and the actions of a firm or a private person in the context of public interests, and to implement the program of the activity focused on the public's understanding and perception;

- PR is a management activity, which establishes mutually beneficial relations between a firm and the public which influences the success of the firm;

- A policy and activity related to disseminating of any information or making a positive image for a person, a firm, a management apparatus, or other organization, is called PR.

While studying the definitions of "Public Relations", the students acquire the skills of making lexical and grammatical constructions of "definition", according to the following models: «Что - это что», «что называется чем», «что называют чем», «что получило название чего» (“smth is smth”, "smth is called smth", etc.).

The foreign students learn the interdisciplinary spheres related to PR and analyze its root causes.

The second lesson is titled as "The goals and the functions of PR". The students analyze the vocabulary linked to the functions of PR specialists' professional activity. The basic terms are: развитие человеческого капитала (human capital development), личностная самоорганизация (personal self-organization), разработка коммуникационной стратегии (the development of communications strategy), анализ информации (analysis of information), управление проектами (project management), организация публичных коммуникаций (organization of public communications), and создание контента (content creation). Then, the students study the grammatical structure of the Russian language and define the subject, the object, the goals and the functions of PR. Grammatical constructions "defining an object/process/phenomenon" such as «что - это что», «что является чем», and «что представляет собой что» ("smth is smth") are practiced, with the basis of the specific vocabulary. The students learn how to form words, transform verb phrases into noun phrases, etc.

The stage is characterized with the focus on teaching students how to form nominative phrases. The students determine the goals and structure of PR specialists' professional activity, 
learning the methods of setting and formulating goals. Generalized occupations in the PR specialists' professional activity are discussed.

The linguistic material of the lesson "Methods of interaction with the public" is intended to explain how to determine a communications strategy, based on a general business strategy of a firm. The foreign students learn communications goals, targets and main theses of communications campaign. The principles, methods and means of goal-setting are of great importance there. The students learn the principles, methods and means of strategic communications planning.

Communications targets are split into several target groups. The skills of determining the right target market/segment/niche (geographic, kitchen markets), to which a company works or is going to work.

The students learn the typical communications strategies for the development and the crises with the help of the specific vocabulary. The skills of making active voice and passive voice constructions are practiced. The practice will provide the formation of skills and methods of identification and segmentation of the target audience; the knowledge of communications means of organizing public and non-public communications; the expertise in the specifics of communications with different types of the target audiences, as well as the basic management skills. The foreign students learn how to compare texts, searching for similarities and differences.

The lesson titled as "The system of marketing communications" is related to the choice of solutions for the formulated problems with maximum results and minimum costs. The foreign students learn how to compare objects/processes/phenomena and express the similarities («что сходно (одинаково) с чем» (“smth is similar (identical) to smth"), «что походит на что» (“smth resembles smth") and differences, both in simple sentences («что отличается от чего чем» ("smth differs from smth in smth"), «что различается чем» ("smth and smth are different in smth"), «в отличие от чего» ("in comparison to smth") and complex sentences («что отличается от чего тем, что» ("smth differs from smth in that..."), «что различается тем, что» ("smth and smth are different in that...").

The students learn how to make a text draft and prepare a short speech on the role of PR in the system of marketing communications.

The lesson named "The product in marketing" familiarizes the foreign students with the notion of «товар» (a product/goods), потребительский спрос (consumer demand), традиционные товары (traditional products), биржевые товары (commodities), промышленные товары (manufactured goods), потребительские товары (consumer goods), товары повседневного спроса (daily necessities), товары экстренного приобретения (emergency goods), товары предварительного выбора (shopping goods), and the classification of goods.

The grammar of the lesson is the components of objects/phenomena. The linguistic skills of using "a part" and "a whole" are practiced.

"The parts and the whole": «что состоит из чего» (“smth consists of smth"), «что включает в себя что» ("smth includes smth"), «что делится на что» ("smth is divided in smth").

"The parts and the whole": «что составляет что» ("smth compounds smth"), «что относится к чему» ("smth is related to smth"), «что входит в состав чего» ("smth is included in smth”), «что образует что» (“smth constitutes smth”), «что является составной частью чего» ("smth is a component of smth").

The students learn how to make schemes according to the material studied. For instance, the students are to speak on the classification of goods with the help of a suggested scheme.

The lesson called "PR companies" is linked to the identification and analysis of stakeholders. The students obtain the skills of expressing their opinion in Russian along with the skills of identification and analysis of communications environment (the media, the leading experts. etc.), and learn how to assess the changes in business and communications strategies, depending on the choice of a stakeholder for communication. The students learn how to express the goal and denote a fact in a simple or a complex sentence, as well as how to make notes.

The lesson called "The market and its functioning principles" is linked to the formation of ideas of market functioning principles. The objects and phenomena are characterized according to the 
following models: «что характеризует что» (“smth characterize smth”), «что характеризуется чем» ("smth is characterized with smth'), «что характерно для чего» ("smth is characteristic for smth"), «что свойственно чему» (“smth is inherent to smth”), «что присуще чему» (“smth in intrinsic to smth"). The students analyse the market. The result of the work is the answers to the following questions:

What is a market? What model characterizes the US market? What characteristics are typical for the French market? What is intrinsic to the Japanese market? What are the possible definitions of a market? What is the first distinctive feature of a market? What is one of the key targets of marketing for all the firms in a market? What situations, indicating the connection between supply and demand, appear in the market? What do you call a market where supply exceeds demand? What characterizes a buyer's market? What is the second distinctive feature of a market? Who are the competitors in the market? What is the third distinctive feature of a market?

The students are supposed to read several texts, divide each text into notional parts, entitle each of them in a form of a noun sentences, make a nominative plan of a text, write down in short the message of each notional part, make theses of a text, retell a text in short, and write the synopsis of the text.

The lesson called "The buyer's behavior" is linked to the analysis of the factors which influence the buyer's behavior and its specifics, depending on age, gender and nationality stratification.

The rest of the lesson includes making notes of special materials which can be used both at the lesson and at home. The texts are adapted and non-adapted passages from the PR speciality textbooks and familiarize the foreign students with the term base and the specifics of their future profession.

In the context of scientific language the foreign students learn how to gather information in Russian. That is why there are exercises focused on analyzing sources of information. For example, the students are supposed to read a text, find the core information, make a plan of the text and answer the questions:

\section{The development of advertising in Western Europe}

In the middle of the $15^{\text {th }}$ century (14401450) the German jeweler and inventor Johannes Gutenberg made the first printing press in the world. That was the beginning of a new era of mass media and advertising. From that time publishing took little time as the printing press provided book publishing in great numbers. After 1450 Europe saw several printing houses appear in Italy, (1465), in Switzerland (1468), in France (1470), in Hungary and Belgium (1473), etc.

Many scholars suppose that the founder of print advertising in Europe was Théophraste Renaudot, a French doctor. In 1630 he opened an inquiry office in Paris, which printed the advertisements for the "La Gazette" newspaper. The first advertisement of the time was the note which offered a reward for the return of 12 stolen horses. Later, the advertisement appeared in a

\section{Развитие рекламы в Западной Европе}

В середине 15 века (в 1440-1450 годах) немецкий ювелир и изобретатель Иоганн Гуттенберг создал первый в мире печатный станок. Это было началом новой эпохи средств массовой коммуникации и рекламы. С этого времени на любые публикации не нужно было тратить много времени, так как печатный станок позволял издавать книги в большом количестве. После этого (во второй половине XV века) в Европе появилось несколько типографических предприятий: в Италии (1465 год), в Швейцарии (1468 год), во Франции (1470 год), в Венгрии и в Бельгии (1473 год) и т.д.

Многие ученые полагают, что основателем печатной рекламы в Европе был французский врач Теофраст Ренодо. В 1630 году он открыл в Париже справочную контору, которая печатала рекламные объявления во Французской газете «La 
newspaper in London. Then many sellers of bread, flour, waffles, tea, coffee and other goods started to give their advertisements in the "La Gazette".

England noted the Industrial Revolution in the mid- $18^{\text {th }}$ century, whereas in the $19^{\text {th }}$ century North America saw a lot of plants and fabrics appear, with different goods and products made. The sellers realized the power of advertising and its effectiveness in getting higher profits.

Over time the printed advertisements began changing. The reason was the invention of photography in 1839 , so the advertisements started combining the information and beautiful photos of a product. Later, special firms and agencies started advertising. In 1990 Philadelphia saw Ayer \& Son, the first advertising agency.

By the way, the first camera was invented in Paris in the 19th century by Joseph Nicéphore Niépce. The French inventor took the first picture in 1822 . It was the view from his window.
Gazette». Самой первой рекламой, опубликованной в это время, было сообщение о награждении за нахождение двенадцати (12) лошадей, которых украли воры. Позднее это рекламное сообщение появилось в лондонской газете. Вскоре начали появляться рекламные объявления от торговцев, продающих хлеб, муку, вафли, чай, кофе и многое другое.

В середине XVIII века началась индустриальная революция в Англии, а в начале XIX века в Северной Америке. Были построены заводы, фабрики, на которых изготавливали разные вещи и продукты. Торговцы поняли силу рекламы и эффективность её использования, чтобы обеспечить себе высокую прибыль.

Со временем стала меняться сама печатная реклама. Это было связано с возникновением в 1839 году фотографии, и рекламная информация стала идти вместе с красивыми фотографиями товара. Позже рекламой начали заниматься специализированные агентства и фирмы. В 1890 году было создано первое рекламное агентство в Филадельфии - «Айер и сын».

Кстати, первый фотоаппарат изобрёл француз Джозеф Ньепс в Париже в 19 веке. Изобретатель Джозеф Ньепс сделал первую фотографию в 1822 году. Он сфотографировал вид из окна.

It is extremely important to teach the technologies of searching for information, first of all, in Russian. The foreign students learn the methods of analytical processing great amounts of content. For instance, they are to find information about Johannes Gutenberg and Théophraste Renaudot in the mass media and prepare a report on Ayer \& Son. The qualitative and quantative analysis of a text's information basis provides the answers to the following questions:

1) Why the middle of the $15^{\text {th }}$ century is called "a new era of mass media and advertising"?

2) Where did the first printing houses appear?

3) Who was the founder of print advertising? What do you know about him?

4) What do you know about the first printed advertisement?

5) Why was advertising developed intensively in the $18^{\text {th }}-19^{\text {th }}$ centuries?

6) What changes did printed advertising see? 
7) Who invented the first camera and took the first picture? When and where did he do that? What did the inventor take picture of?

Specific vocabulary is paid a special attention. The students are to study a list of professional words and phrases with their definitions, which the students must comprehend on order to understand the theoretical materials.

Let us give some examples:

Приглашение (Invitation). Invitations to attend an event (e.g. an exhibition or a press conference) are printed on the one side of a folded piece of strong paper or a fiber-based paper, which can easily fit an envelope. Invitations are delivered either via mail or by messenger.

The text of an invitation should be brief and include the name of the event, its time and venue; one should indicate the public transport links, close to the venue. An invitation should contain an implicit promise of an interesting quality time either because of the theme or because of the names of famous people who are to participate in the event.

An invitation is usually addressed to a certain person and starts with the words "Dear" or "Dearest" and the name (in Russia first name and patronymic name) of the addressee.

Проспект (Prospectus). A prospectus is a calling card of a firm. Such a prospectus has a certain lifespan and changes according to the changes in the firm's mission, structure, activities, people in the management, etc.

Prospectus calendars are made by many organizations in order to mail and hand them out with New Year's greetings. The aim is to remind about the existence of the firm, that is why the logo and the slogan of the firm are the intrinsic part of prospectus calendars, as well as its address and telephone number for the future communications.

\section{A typical prospectus consists of:}

1) the first, title page with minimum text on it. It contains the title, an illustration, a firm's $\log 0$ and slogan;

2) inner pages, designed in the same way, with the combination of texts and illustrations; headings and sub-headings can be used in each inner page;

3) superimposing a text on a color illustration is not recommended because of its illegibility, as well as the fonts composed only of capital letters.

Брошюра(Brochure). A brochure is not periodical, so it is created anew every time, with a special purpose. Brochures are distributed by a firm either as an independent product or as a part of the materials kit and, thus, must have an attractive design.

The purpose of the brochure is to attract interest, answer the possible questions and indicate the sources of further information. The main purposes of brochures are to inform, to convince and to raise awareness. However, a brochure should never contain the facts from the previous versions.

\section{Conclusiones}

The research has demonstrated that communicative competence is basic as PR specialists' activity presupposes constant communication.

The communication-oriented education determines the integration of the language in the system of vocational training for PR students in order to achieve real goals in the professional activity. The practical course of the Russian language plays a vital role in the vocational training.

During their Russian language lessons the PR foreign students learn to make contacts with different people, make a good impression on them, enter different types and forms of business communication, apply the conviction and influence strategies in practice, etc.

In the conditions of vocation-oriented training of future PR specialists the skills of processing information in Russian are of great importance. When studying scientific language, the students learn how to make press releases, reports, articles, scenarios, etc.

Processing information is a kind of activity which has the strongest cognitive, emotional and moral potential, and contains diverse and greater amounts of content and a plenty of room for thought which is extremely important for a student's personal development. 


\section{Referencias}

Adonina, L.V., Adonin, R.F. \& Fisenko, O.S. (2017) Cognitive trend in modern science of language: materials for the organization of academic work in classes of the philological profile. Language and Personality in a Multicultural Space. Digest of articles. Edited by I.N. Avdeeva, Moscow, Russia, 134-143

Adonina, L.V., Lazarev, S.V., Matveenko, V.E., Fisenko, O.S. \& Chernova, N.V. (2017) In the world of PR. A training manual for "Public Relations" speciality foreign students. [Ed.: Lazarev S.V.]. Russia, Moscow, 50

Fisenko, O., Nikitina, \& V. Bodrova, T. (2019) Semantic-cognitive approach to the study of a language person in the system of human and individual values. Chile, Santiago, 106112

Fisenko, O.S., Tazheva, Z.B. \& Masyuk, M.R. (2019) Contents and structure of a concept "Russian" in language consciousness of Tajiks. Revista Inclusiones. Vol: 6. № 2, p. $150-159$

Kargina, N.V., Fisenko, O.S. \& Polyanskaya E.N. (2017) Technology of social manament in organization in the Russia federation: the theoretical aspect. The Turkish online Journal of Design Art and Communication TOJDAC, December 2017 Special Edition, 1970-1979

Koreneva, A.V. (2009) Vocation-related communication training of non-philological speciality students, based on an interdisciplinary integration. Abstract of Ph. D. thesis. Russia, Moscow, 41

Litvinenko, E.V. (2007) The criteria of selecting vocation-oriented texts in technical universities. Psychological and pedagogical and linguistic methodical aspects of teaching at universities. Kharkiv, KHADI, 420

Obraztsov, P.I. \& Ivanova, O.Yu. (2005) Vocation-oriented teaching foreign languages at nonlinguistic departments. Russia, Oryol, 114

Vishnyakov, S.A. \& Dunaeva, L.A. (2017) Foreign-language verbal communication: teaching, studying, comprehending in the context of environmental approach: a monography, Russia, Moscow, 168

Zharinova, T.N. (1999) The problems of teaching Russian to foreign specialists and the solutions. Teaching foreign specialists at universities: problems, tendencies, solutions, Russia, Tver, 45-49

*This paper has been support by the RUDN University Strategic Academic Leadership Program. 